\title{
The Ethics and the Meaning of Life among College Students
}

\author{
Maria Helena de Agrela Gonçalves Jardim 1,2,3, Geraldo Bezerra da Silva Junior3, \\ Márcia Lúcia Sousa Dias Alves ${ }^{4,5}$, Bruna Raquel Figueira Ornelas de Gouveiaa,7, Rita Baptista Silva ${ }^{4,7}$
}

${ }^{1}$ School of Health, University of Madeira, Funchal, Portugal

${ }^{2}$ Visiting Researcher at UNIFOR by Capes/Funcap, Fortaleza, Brazil

${ }^{3}$ Health Sciences Center, University of Fortaleza, Fortaleza, Brazil

${ }^{4}$ Hospital of Dr. Nélio Mendonça, Madeira, Portugal

${ }^{5}$ Abel Salazar Biomedical Sciences Institute, University of Porto, Porto, Portugal

${ }^{6}$ School of Nursing of São José de Clunny, Funchal, Portugal

${ }^{7}$ Nursing Sciences, University of Porto, Porto, Portugal

Email:hjardim@uma.pt,geraldobezerrajr@unifor.br,marcialves96@hotmail.com,bgouveia@esesjcluny.pt,ritamlbs@hotmail.com

How to cite this paper: de Agrela Gonçalves Jardim, M.H., da Silva Junior, G.B., Alves, M.L.S.D., de Gouveia, B.R.F.O. and Silva, R.B. (2018) The Ethics and the Meaning of Life among College Students. International Journal of Clinical Medicine, 9, 221-233.

https://doi.org/10.4236/ijcm.2018.94019

Received: January 26, 2018

Accepted: April 8, 2018

Published: April 11, 2018

Copyright $(0) 2018$ by authors and Scientific Research Publishing Inc. This work is licensed under the Creative Commons Attribution International License (CC BY 4.0).

http://creativecommons.org/licenses/by/4.0/

\section{cC) (i) Open Access}

\begin{abstract}
The concern of the ethics and the meaning of life in young adults became universal and are present in all contexts of human life. Such universality is due to the development of modern rationality, to establish a relationship between the intrinsic theoretical dimensions (scientific) and practical dimensions (ethical), originated that are present in the own array of knowledge. This descriptive cross-sectional study, aims to identify the values of the ethical dimension and meaning of life defended by the college students of the Universities of Madeira, Portugal and Fortaleza, Brazil. The sample consists of 605 University students (Madeira $=225$ and Fortaleza $=380$ ), with an average age of 21 years and a standard deviation of 2 . We used the questionnaire on values (adapted from the European Values Survey). Most of the young people referred to have a religion ( $60 \%$ wood and $78.4 \%$ stronghold), being the most Catholic, however, present in your frequency disinterest and, yet, in Brazil there is a greater diversity of religions. Supporting the intervention of religious institutions in situations of everyday life is accepted mostly by Brazilians, with the exception of politics (35.5\%). On the other hand, the university students of the University of Madeira understand that Religious Institutions should only give their opinion on racial discrimination (76.6\%). Believe in God (90.8\% and 55.1\% Stronghold) and Soul (80.3\% and 66.4\% Stronghold) are beliefs more referred to by college students. These results are intended to contribute in the field of research on ethical values and meaning of life in young people. This study contributes to future comparative research among
\end{abstract}


university students and to developing strategic programs in education and health, increasing the success and excellence in the formation of a full citizenship, preventing the fanaticisms and the social discrimination that today devastate the collective globally.

\section{Keywords}

Values, Ethics, Meaning of Life, Young Adults, College Students, Questionnaire on Values (QSV)

\section{Introduction}

The society covers the young as a driving force of social change determinant in the development of the modernization of social structures. Students are the result of the environment and, at the same time, religion does not dissociate itself from the collective, diminishing the monopoly and symbolism of religious institutions, determined the emergence of different expressions of faith. Being the young face of the sociocultural, economic and political developments, the progress of a community depends on your ability to incorporate them.

Most students claim to be Catholic. However, religious practice is limited to festive acts and occasional rituals. It is intended with this research to identify the religious profile of University students of Madeira, Portugal and Brazil in Fortaleza and its forms of expression, in terms of religious beliefs, trying to reflect about the incentives that move young people into society modern, as well as the idealism that characterizes this age.

Religion functions as a system comprising public relations standards, trained in social institutions and interdependent groups, based on rules and own resources, of which separate beliefs, practices, symbols, world views, values, associations and experiences [1].

There is a multitude of definitions and concepts attributed to religion, given the subjective nature of matter and the importance and meaning that each one gives [1]. The author defines religion as the belief in spiritual beings so that people can interpret their experience and organize their conduct, attributing meaning to the phenomena perceived in the world and in itself.

The sacred concept would allow the junction between religion and spirituality. The spirituality would be the search of meaning of life, while religion was organizational, defined the ritual and the ideological [2]. In this way, the spirituality would become a central function of religion.

In the past, religion was extremely appreciated. Older people attended the church together with their families and taught the prayers to the children from an early age and, thus, people looked to religion as one of its largest holders of life. Currently, these traditions began to take other directions, which demonstrate that only older people and some adults attend the churches, being teens 
the least interested.

The religious question now lives a complex and diverse process of transformation in relation to Catholic hegemony, discovering new forms of religious expression in different places [3]. Issues such as pluralism, citizenship, religious freedom, transversality, metamorphoses and secularization of religious help explain and translate the story of the religious phenomenon in Portugal throughout the ages. This phenomenon has been redefined in the face of history and society, having survived several times to your ads disappearance [4].

In recent decades the religious question, suffered a set of transformations and reconfigurations, causing within the Portuguese society, diverse sensibilities and ways of acting to the detriment of the religious situation. We are witnessing a progressive wear of the customs and traditions of institutional religion, leading religious organizations not only to an unprecedented crisis, but also to a loss of influence of the Church in the Portuguese society. There is currently a reconfiguration of Catholicism by issuing of opinions from certain ethical-moral and social aspects of modern society and that, in the light of Christian principles, are seen as negative and of discord [5]. The religious question lost gradually, your representation within the Portuguese society, referring your role for the social dimension based on the criticism of some decisions that are taken by the society and that are based on ethical, social and political aspects, however retaining some traditional customs.

The principle of secularization is that religion is losing successively essential part of your impact on social life, manifesting itself in two dimensions, such as: the individualization of the beliefs/moral practices and the discrediting of institutions, leading to (des) institutionalization [4].

Today Catholicism offers increasingly difficulties in defence and affirmation of your domain, either as to the religious practice, as in the transmission of religious content from generation to generation. However, to tackle the question of secularization, tries to assert itself and reconfigure itself continuously in the field of political, ethical, aesthetic values, exercising your opinion in the media [5].

Fundamentally, it is noted that Catholicism lived different stages that alternated between secular and Catholic. Currently, although there are clear traces of a more secularized society, Portugal and Brazil are governed by their traditional Catholic values and for obvious signs of a widespread Catholicism, that are crucial in exerting influence shaping behaviours and attitudes in social life, and reconfiguring a society [5].

Young people are by nature unhappy beings, express your opinion and your views in relation to current situations and the problems they face. They are the result of generation and society that surrounds them [6]. Youth and religion cross a long circumstantial accompanying the pace of society. The relationship that young people establish with religion is characterized by the primacy of the individual and earthly happiness, the desire for independence and autonomy, by relativism and by pragmatism [7]. Another relevant factor on the religious ques- 
tion of young people concerns the family, seen as the main institution of religious education, responsible for transmitting from generation to generation of customs, traditions and beliefs. Within familiar young people express their specificities and Diversities, building and shaping your identity to the detriment of the religious question. However, this transmission of values in the family is currently at risk, since: the tradition does not hold individual and collective life; the faith is not at the expense of legitimate tradition, but from your utility; the beliefs are not received passively, but are actively consumed [7]. In addition to these short-term factors, the changes at the level of the family contribute to the breaks with the religious, namely: civil marriage in opposition to church wedding; the fact that people choose to marry less and less and later; divorces; the low birth rate; new family settings and other. All these factors compromise the religious experience and the passing of values and customs from generation to generation within families.

The religion to have a decisive role in the lives of believers, repeatedly is associated with various psychological disturbances, being included in the beliefs and experiences of psychotic patients. According to [8] most psychiatrists and other mental health professionals, scientifically trained, believes in a secular, scientific view of the world, in other words, have a sceptical view of religion, believing that they can see, hear, touch and taste through the methodical reasoning. The author points out that Sigmund Freud believed that religion caused neurotic and psychotic symptoms and that, in the years 60 , declared religion as the universal obsessional neurosis of humanity. This advocated that religion included obsessive restrictions, with a system of full illusions of desire with repudiation of reality as notes in psychiatric disorders. He goes further, referring to religion as a hallucinatory state of confusion. This negative view of religion in terms of mental health, remained until modern times, being defended by several authors, who noted the irrational nature of religious beliefs, even refer to your potential pernicious [9], mention that the personal religious beliefs of psychiatrists and psychologists and other health professionals, when compared with the general population, reflected also the secular and negative views of religion, which are prevalent in these professions. This is because, for years, religious people are portrayed as examples of psychiatric diagnostic manuals. This negative perspective with regard to religion, had no objective research based, but personal opinions and clinical experiences of influential people within the psychiatric academy members.

This attitude to religious, caused that religious communities developed [9], negative attitudes in relation to psychologists and psychiatrists considering them often as useless. This conflict has led to several lawsuits in the United States, due to religious communities not forward its members serious mental diseases to psychiatric care, bringing with devastating results. According to [8], both sides of the conflict are wrong. On the one hand, the religious beliefs of a person relate to your culture, education, values and subjective vision of reality and must be 
respected, considered normal/healthy, because they can help overcome inner dilemmas and answer the existential issues disturbing, such as the meaning of life, overcoming grief situations, among others. On the other hand, the monitoring of these people will have to be done by a competent mental health professional, if they are suffering from a psychological disorder and not only devoted.

Pathological and non-pathological situations in which the religious fanaticism is taken to the extreme, we were faced with a serious problem that often leads to religious extremist groups that convey the latest generations their visions of what is right and wrong according to the will of a superior entity. A prime example of this is the acts of terrorism with religious motivations. These acts are a huge threat to global security. In addition, terrorism in the European Union, in addition to putting lives at risk and having substantial costs, profoundly undermines the openness and tolerance of our societies and represents a growing strategic threat for the whole of Europe [10]. Terrorist movements have increasingly important resource, are linked together through electronic networks and are ready to resort to violence without limits with the aim of causing a large number of victims. The recent waves of terrorism are global and are linked to religious extremism from violent character. On your origin can highlight several reasons correlated, the pressures for modernisation, cultural, social and political crises, and the alienation of young people living in foreign societies. The same author notes that Europe is both a target and a base for terrorism, with European countries that have been designated as target and suffered attacks, but also logistics bases were discovered of terrorist cells in the United Kingdom, in Italy, in Germany, in Spain and Belgium [11].

The latest terrorist threat, the self-proclaimed Islamic State (jihadist) is a religious group with carefully thought-out beliefs, among them being the agent of the approaching apocalypse, rejects peace is a matter of principle, causing the biggest genocide ever the history of humanity, the agent and principal author of the end of the world, which according to these, is imminent. Many Islamists have manifested itself, saying that everything this Organization stands for and intend to do goes against the principles of Islam, however the religion preached by their most ardent followers comes from a coherent interpretation of Islam, even though they have attracted psychopaths and people looking for adventure, out especially the marginalized populations of the Middle East and Europe, educate the children/young people from an early age to line up on your crusade, recruiting followers also in the West. It is thought that the target population young troubled teens who follow the faith or are willing to convert, making them aware for the cause [12]. At this stage the young man begins to open up to the future, the body grows, develops the mentality and personality, summarised in the restless attempt of his own achievement and appreciation of things, psychic process which affects the moral conscience still non-consolidated the will and the morality of the teenagers a chaos of contradictions. Some of them are enticed because they feel powerless to synthesize all the dispersion created in themselves, 
in particular, the physical growth, sentimental arousal associated with all problems of love, the doubts of intelligence, as well as all the problems related to the faith and morals [13]. This is an example of the dangers of religious fanaticism, because there is a part of the Islamic community which, although they are devotees and practitioners, have a different interpretation of religion and follow peaceful and healthy practices. While there are organizations, which they call themselves apocalyptic agents and want to dominate and terrorise the world through various genocides, declaring war against the "infidels".

\section{Methodology}

Many of the assumptions listed inculcated the purpose of the present study in the University of Madeira and of Fortaleza, training places for young people to full citizenship, comparing two geographic and cultural contexts, which aims to identify the dimension of values-Ethics and Sense of Life of University students through a descriptive and comparative research.

The sample consists of a significant population of University students ( $\mathrm{n}=$ 605) 225 of the University of Madeira (UMa) and 380 of the University of Fortaleza (UNIFOR). The data collected in the context of classroom and/or on Campus, before or after school, in different courses, selected at random from all centres of universities. As inclusion criteria we have young people who attend the graduate courses, aged between 18 and 24 years, being excluded not included on age group established, attending postgraduate courses and those who do not complete the questionnaire. In addition to issues of demographic characterization, the structured questionnaire on values, consisting of 30 compound issues grouped by 6 dimensions of values under study and that are: Individual Wellness; Interpersonal Relationships; Participation and Social intervention; Ethics and Sense of life; Family and Socio-political values. The data collection took place in the year 2017, after approval by the Ethics Committee, and participants were elucidated the confidentiality and anonymity of the results, the objectives of the study and the consequent disclosure forecast, giving your informed consent at the time of the completing the questionnaires. Were also informed they could quit at any time during participation, without any damage. Descriptive statistics was used by the calculation of frequencies, averages, sets, standard deviation and minimum and maximum values.

In this article we'll cover the dimension-ETHICS and SENCE of LIFE which includes issues such as: Intervention of religious institutions; Content and religious practices; Religious Profiles and Frequency to acts of worship.

\section{Results}

The average distribution by ages of students of UMa is of 21.38 and UNIFOR is 20.94, with a standard deviation of 2.0 and 1.95 respectively. The minimum value is located in the 18 years of age and the maximum in 24 years (Table 1). The majority are female (65.3\% UMa and $74.2 \%$ UNIFOR) and single (96.0\% 
UMa and $96.3 \%$ UNIFOR). With regard to place of birth on UMa the majority is Portuguese (96\%) and in UNIFOR Brazilian (94.2\%). As regards the race most is White (96.0\%) and Brown (55.0\%), respectively in UMa and in UNIFOR.

Concerning the opinion on the intervention of religious institutions, most of the population of UMa says that should give instructions to their faithful (Table 2) about racial discrimination (56.4\%) and a significant proportion considers that may express an opinion on social justice (45.3\%). In the case of UNIFOR the situation is distinct since most agree with the interference of the Church in everyday problems. In contrast, most students of UMa believes that these institutions should not opine on the remaining problems, mostly politics (76.4\%), sexual relations outside of marriage $(73.8 \%)$, homosexuality $(69.3 \%)$, abortion and birth control (67.2\%) and euthanasia (66.2\%), while in UNIFOR most (64.5\%) only argues that the churches should not give instructions about politics.

A study conducted in Taiwan [14] with 248 students Christians and non-Christians 356 students, revealed there are significant relationships between spirituality and high scores of decision making to the career/job. To investigate the relationship between religiosity and the use of drugs among Brazilian University students $(n=12,595)$ [15], found that religiosity is adopted and seen as strongly protective factor against drug use (alcohol, tobacco, marijuana and

Table 1. Descriptive statistics of the age of young people by University.

\begin{tabular}{cccccc}
\hline & $\mathrm{N}^{\circ}$ & Minimum & Maximum & Average & $\begin{array}{c}\text { Standard } \\
\text { Deviation }\end{array}$ \\
\hline UMa & 225 & 18 & 24 & 21.38 & 2.00 \\
UNIFOR & 380 & 18 & 24 & 20.94 & 1.95 \\
\hline
\end{tabular}

Table 2. The churches should give instructions to their faithful.

\begin{tabular}{|c|c|c|c|c|c|c|c|c|}
\hline \multirow{3}{*}{ Give instructions to their faithful about: } & \multicolumn{4}{|c|}{ University of Madeira } & \multicolumn{4}{|c|}{ University of Fortaleza } \\
\hline & \multicolumn{2}{|c|}{ Yes } & \multicolumn{2}{|c|}{ No } & \multicolumn{2}{|c|}{ Yes } & \multicolumn{2}{|c|}{ No } \\
\hline & $\mathrm{n}$ & $\%$ & $\mathrm{n}$ & $\%$ & $\mathrm{n}$ & $\%$ & $\mathrm{n}$ & $\%$ \\
\hline Disarmament & 77 & 34.2 & 148 & 65.8 & 197 & 51.8 & 183 & 48.2 \\
\hline Abortion and birth control & 74 & 32.9 & 151 & 67.2 & 215 & 56.6 & 165 & 43.4 \\
\hline Problems of the third world & 110 & 48.9 & 115 & 51.1 & 212 & 55.8 & 168 & 44.2 \\
\hline Sexual relations outside of marriage & 59 & 26.2 & 166 & 73.8 & 229 & 60.3 & 151 & 39.7 \\
\hline Unemployment and labor relations & 99 & 44.0 & 126 & 56.0 & 221 & 58.2 & 154 & 41.8 \\
\hline Racial discrimination & 127 & 56.4 & 98 & 43.6 & 291 & 76.6 & 89 & 23.4 \\
\hline Euthanasia & 78 & 33.8 & 149 & 66.2 & 246 & 56.8 & 164 & 43.2 \\
\hline Homosexuality & 69 & 30.7 & 156 & 69.3 & 201 & 52.9 & 179 & 47.1 \\
\hline Ecology and environment issues & 92 & 40.9 & 133 & 49.1 & 225 & 59.2 & 155 & 40.8 \\
\hline Politics & 53 & 23.6 & 172 & 76.4 & 135 & 35.5 & 245 & 64.5 \\
\hline Social justice & 102 & 45.3 & 123 & 54.7 & 266 & 70.0 & 114 & 30.0 \\
\hline
\end{tabular}


illicit drugs by least one), but further studies are needed to identify the mechanisms that lead to religiosity to exercise this extension. [16] showed that young adults Christians and Muslims believers, reveal more negative attitudes toward homosexuality than non-Muslims. Another survey, by [17], has shown that college students in Saudi Arabia, despite living in a strict Islamic society, they feel an integral part of the connected generation worldwide and using essentially the networks as social communication process.

With regard to the contents and religious practices, beliefs (Table 3) more mentioned by respondents from UMa were believing in the Soul (64.4\%) and God (55.1\%). Those in which the population of Madeira not believe mostly are: infallibility of the Pope and the proximity of the end of the world both with $81.3 \%$, following the Hell (76\%), original sin (72.8\%), Devil (72.4\%), Paradise (70.7\%) the virginity of Mary (69.8\%) and reincarnation (68\%). In contrast, students at UNIFOR mostly admit all faiths, with the exception of reincarnation (53.7\%), infallibility of the Pope (69.7\%) and end of the world (65.0\%), reflecting the religious and mystical load that the Brazil contains. In General, the fact that the college students of wood are predominantly Catholics should influence the adherence to religious beliefs which we have just mentioned, which is not the case. It is assumed that this may be due to the conservatism of Catholic doctrine in Portugal. On the other hand, the college students of UNIFOR transmit the mystical and religious load of Brazil.

With regard to religious profiles, the majority (60\% UMa and 78.4\% UNIFOR) reveals to have a religion, being mostly referred to the Catholic (59.6\% UMa and $48.4 \%$ UNIFOR) (Table 4). However, $40 \%$ and $21.6 \%$ referred to be

Table 3. Beliefs.

\begin{tabular}{cccccccccc}
\hline \multirow{2}{*}{ Believe in: } & \multicolumn{3}{c}{ University of Madeira } & \multicolumn{3}{c}{ University of Fortaleza } \\
\cline { 2 - 10 } & \multicolumn{2}{c}{ Yes } & \multicolumn{2}{c}{ No } & \multicolumn{2}{c}{ Yes } & \multicolumn{2}{c}{ No } \\
\cline { 2 - 11 } God & $\mathbf{n}$ & $\%$ & $\mathbf{n}$ & $\%$ & $\mathbf{n}$ & $\%$ & $\mathbf{n}$ & $\%$ \\
\hline Life after death & 124 & 55.1 & 121 & 44.9 & 345 & 90.8 & 35 & 9.2 \\
Soul & 105 & 46.7 & 120 & 53.3 & 254 & 66.8 & 126 & 33.2 \\
Devil & 145 & 64.4 & 80 & 35.6 & 305 & 80.3 & 75 & 19.7 \\
Hell & 62 & 27.6 & 163 & 72.4 & 251 & 66.1 & 129 & 33.9 \\
Paradise & 54 & 24.0 & 171 & 76.0 & 249 & 65.5 & 131 & 34.5 \\
Sin & 66 & 29.3 & 159 & 70.7 & 277 & 72.9 & 103 & 27.1 \\
Original sin & 97 & 43.1 & 128 & 56.9 & 275 & 72.4 & 105 & 27.6 \\
Resurrection of the dead & 63 & 28.0 & 162 & 72.8 & 208 & 54.7 & 172 & 45.3 \\
Reincarnation & 51 & 22.7 & 174 & 77.3 & 193 & 50.8 & 187 & 49.2 \\
Divinity of Christ & 72 & 32.0 & 153 & 68.0 & 176 & 46.3 & 204 & 53.7 \\
Virginity of Mary & 85 & 37.8 & 140 & 62.2 & 298 & 78.4 & 82 & 21.6 \\
Infallibility of the Pope & 68 & 30.2 & 157 & 69.8 & 259 & 68.2 & 121 & 31.8 \\
End of the world next & 42 & 18.7 & 183 & 81.3 & 115 & 30.3 & 265 & 69.7 \\
\hline
\end{tabular}


atheist or agnostic. In our opinion, this percentage is significant for revealing detachment of young people vis-à-vis the religious domain. We see this trend in several studies. [18] published an article he contributed to the understanding of the diversity of beliefs and practices among young people who reveal the absence of a specific religious faith. It focuses on those who call themselves as atheist, agnostic or other form of "no religion", revealing that are Caucasian and born in Britain. There was, however, diversity of beliefs and practices: some mention some level of belief in God, showing a considerable fluidity because they claim some presence of religion throughout their life cycles. Other participants said they had held religious views similar to mothers, but that the impact of their experiences and interactions, as well as the role of science, interfered as factors that affected their beliefs and practices.

As already mentioned earlier most students referred to have Catholic faith. In Table 5 we find that there is greater diversity in UNIFOR of religions including Judaism (11.1\%), Spiritualist (10.0\%), Evangelical (5.5\%), Presbyterian (1.6\%) and other, while at the University of madeira there is only a negligible proportion $(0.9 \%)$ of evangelicals. This Catholic dominance does not correspond to an actual religious practice.

Noting the referring on the frequency to acts of worship (Table 6), as referred to by the Catholic population is once a week (18.2\%, UMa and $28.9 \%$ UNIFOR), followed by the very rarely or never (15.6\%, UMa and $16.8 \%$, UNIFOR) and once or twice a month (10.7\%, UMa and $17.1 \%$ UNIFOR). The data obtained, again reflected an increase of motivation of Catholic worship practices, some same attend them for religious ceremonies (weddings, mourning masses, baptisms) with $15.6 \%$. In line, [19] notes that the rites of passage like weddings or christenings and presence at parties or local festivals, are currently the main forms of manifestation of the Portuguese society on the question of religion.

In a longitudinal study conducted in [20], found that college students are significantly less religious than the teenagers who attend high school and/or high school. Concern that, although the majority of teens and young adults are still involved religiously, rarely attend religious services, these are less likely to say that religion is important in their lives, spend less time praying or meditating, causing declines in religious orientation, leading to a move towards secularism. The declines are more evident among the female and Caucasian. In line, [21] claims that the young Portuguese say feel religious, but are increasingly uncompromised with the Church.

Table 4. Religion.

\begin{tabular}{ccccc}
\hline \multirow{2}{*}{ Do you have any Religion } & \multicolumn{2}{c}{ University of Madeira } & \multicolumn{2}{c}{ University of Fortaleza } \\
\cline { 2 - 5 } & $\mathrm{n}$ & $\%$ & $\mathrm{n}$ & $\%$ \\
\hline Yes & 136 & 60.0 & 298 & 78.4 \\
Is atheist or agnostic & 90 & 40.0 & 83 & 21.6 \\
Total & $\mathbf{2 2 5}$ & $\mathbf{1 0 0 . 0}$ & $\mathbf{3 8 0}$ & $\mathbf{1 0 0 . 0}$ \\
\hline
\end{tabular}


Table 5. Kind of religion.

\begin{tabular}{ccccc}
\hline \multirow{2}{*}{ Kind of Religion } & \multicolumn{2}{c}{ University of Madeira } & \multicolumn{2}{c}{ University of Fortaleza } \\
\cline { 2 - 5 } & $\mathrm{n}$ & $\%$ & $\mathrm{n}$ & $\%$ \\
\hline Catholic & 134 & 59.6 & 184 & 48.4 \\
Evangelical & 2 & 0.9 & 21 & 5.5 \\
Spiritualist & - & 0.0 & 38 & 10.0 \\
Christian & - & 0.0 & 2 & 0.5 \\
Judaism & - & 0.0 & 42 & 11.1 \\
Adventist & - & 0.0 & 1 & 0.3 \\
Protestant & - & 0.0 & 2 & 0.5 \\
Presbyterian & - & 0.0 & 6 & 1.6 \\
Messianic & - & 0.0 & 1 & 0.3 \\
\hline
\end{tabular}

Table 6. Often in acts of worship for educational institution.

\begin{tabular}{ccccc}
\hline \multirow{2}{*}{ Frequency } & \multicolumn{2}{c}{ Madeira } & \multicolumn{2}{c}{ Fortaleza } \\
\cline { 2 - 5 } & $\mathrm{n}$ & $\%$ & $\mathrm{n}$ & $\%$ \\
\hline More than once a week & 7 & 3.1 & 30 & 7.9 \\
Once a week & 41 & 18.2 & 110 & 28.9 \\
Once or twice a month & 24 & 10.7 & 65 & 17.1 \\
At Christmas and Easter & 18 & 8.0 & 5 & 1.3 \\
The party of the Patron Saint/other Saints & 4 & 1.8 & 7 & 1.8 \\
In the baptisms, weddings and funerals & 13 & 5.8 & 17 & 4.5 \\
Very rarely or never & 35 & 15.6 & 64 & 16.8 \\
\hline
\end{tabular}

Religious issues are important aspects of the identity of the educational process and for many young adults can be intensified by the University experience. A study of [22] the heterogeneity in religiosity being evident according to gender and religious affiliation, and modified the orientation of students during this period of academic development.

\section{Discussion}

The data reveal that most UMa students evidence an increased shift from the religious to the secular, albeit not in a linear way, that is, the traditional Portuguese Catholicism adapts depending on the times and the needs imposed by society, characteristic of secularization, in adopting a critical attitude, through interventionist acts, to the cultural and social life. In this sense, the authors [19] declare that "Portugal is a country at the same time modern, secularized, religious and Catholic", with harmony between religion and modernity. On the other hand, students of UNIFOR refer to a religious load superior and diversified, despite seeing an increase of atheists and agnostics (21.6\%) in a country that is famous for your religious and spiritual belief.

The implications of [23] research with students from the University of Chi- 
cago, about spiritual growth and religious students during college and the conditions under which they grow in their religious lives, are abundant. The author argues that universities must provide the existence of safe places for students to explore and express their beliefs, doubts and struggles, finding a meaning for life, in a world in constant change. Conditions can be created in the classroom and in social settings on campus with colleagues who provide spiritual, social and moral growth for the student's holistic development. The creation of favourable environments and discussion of ideas promoted by the University will promote in the student spiritual and religious development, as well as academic growth, such as the development of their own values, beliefs, as well as the exchange of experiences and knowledge of other religious. Teachers should recognize the significance that intimate and spiritual life has for students by providing group activities that develop reflection and meditation skills about faith and the meaning of life. The entire academic community needs to recognize that private and spiritual life of students is very significant for them.

This study is based the reflection on the theme of the values defending by young people from higher education of UMa and Fortaleza. In the future, we plan to compare the values between the two contexts in cultural terms, aiming at the improvement of civics, with the imprint of the paradigmatic values that nowadays young people value most.

Given the serious implications that the direction of science and technology has to vital areas of people, society and nature, ethics, the justification of moral values and moral education became universal concern [24]. All the work is before us by the look of education. The study [24] explores the contributions of the teachers for religious pluralism and interfaith cooperation in higher education. The authors propose a preliminary model of professional skills, consolidating a systemic vision around the educational and socialization processes, to engage in effective conversations with students about issues of religion, spirituality, secularism and faith.

The response of Universities is still deficient as regards the formation of full citizenship with principles, freedoms and guarantees, for and with everyone. We can emphasize that there are few university courses that contemplate the ethical dimension and the meaning of the life of the students in their curricula. This research aims to contribute to the inclusion of a common discipline called ethics and citizenship in order to reinforce the success and excellence of values in the youth of this millennium.

\section{References}

[1] Coutinho, J. (2012) Religião e outros Conceitos. Sociologia. Revista da Faculdade de Letras da Universidade do Porto, 24, 171-193.

[2] Pargament, K.I. (2001) The Psychology of Religion and Coping: Theory, Research, Practice. Guilford Press, London, 548 p.

[3] Teixeira, A. (2012) Identidades Religiosas em Portugal: Representações, Valores e Práticas, 2011. Universidade Católica Portuguesa, Centro de Estudos e Sondagens 
de Opinião \& Centro de Estudos de Religiões e Culturas.

[4] Duque, E. (2014) Mudanças Culturais. Mudanças Religiosas. Perfis e Tendências da religiosidade em Portugal numa perspectiva comparada. Editora Húmus, Vila Nova de Famalicão, 338 p.

[5] Duque, E. (2007) Os jovens e a religião na sociedade atual. Comportamentos, crenças, atitudes e valores no distrito de braga. Edição de Secretaria de Estado da Juventude.

[6] Secretariado Nacional da Pastoral da Cultura (s.d.) Catolicismo e "outras identidades religiosas em Portugal. Jovens, Religião e Família nos últimos 20 anos”. http://www.snpcultura.org/catolicismo_e_outras_identidades_religiosas_em_portu gal_interpretacao.html

[7] Koenig, H. (2007) Religião, espiritualidade e transtornos psicóticos. Revista de Psiquiatria Clínica, 34, 95-104. https://doi.org/10.1590/S0101-60832007000700013

[8] Curlin, F.A., Lantos, J.D., Roach, C.J., Sellergren, S.A. and Chin, M.H. (2005) Religious Characteristics of U.S. Physicians. Journal of General Internal Medicine, 20, 629-634. https://doi.org/10.1111/j.1525-1497.2005.0119.x

[9] Folgado, P.N. (2016) Portugal e o Combate ao Terrorismo-A Estratégia Nacional Pedro Naves. Proelium, 7, 335-347.

[10] União Europeia. (2003) Uma europa segura num mundo melhor. http://ftp.infoeuropa.eurocid.pt/database/000021001-000022000/000021590.pdf

[11] Público (2015) O que é o estado islâmico? Graeme Wood. Jornal o Público. http://www.publico.pt/mundo/noticia/o-que-e-o-estado-islamico-1690458

[12] Rodrigo \& Palacios (2003) Família e desarollo humano. Alianza, Madrid.

[13] Peng, H. and Chen, M. (2014) The Study of Spirituality, Work Value and Career Decision-Making between Christian and Non-Christian College Students. The Journal of Happiness \& Well-Being, 2, 63-74.

[14] Gomes, F.C., Andrade, A.G., Izbicki, R., Moreira-Almeida, A. and Oliveira, L.G. (2013) Religion as a Protective Factor against Drug Use among Brazilian University Students: A National Survey. Revista Brasileira de Psiquiatria, 35, 29-37. https://doi.org/10.1016/j.rbp.2012.05.010

[15] Roggemans, L., Spruyt, B., Droogenbroeck, F.V. and Keppens, G. (2015) Religion and Negative Attitudes towards Homosexuals: An Analysis of Urban Young People and Their Attitudes towards Homosexuality. Young, 23, 254-276. https://doi.org/10.1177/1103308815586903

[16] Ezzi, S.W., Teal, E.J. and Izzo, G.M. (2014) The Influence of Islamic Values on Connected Generation Students in Saudi Arabia. Journal of International Business and Cultural Studies, 9, 1-19.

[17] Madge, N. and Hemming, P.J. (2017) Young British Religious "Nones": Findings from the Youth on Religion Study. Journal of Youth Studies, 20, 872-888. https://doi.org/10.1080/13676261.2016.1273518

[18] Dix, S. (2010) As Esferas Seculares e Religiosas na Sociedade Portuguesa. Revista Análise Social, 194, 5-27.

[19] Twenge, J.M., Exline, J.J., Grubbs, J.B., Sastry, R. and Campbell, W.K. (2015) Generational and Time Period Differences in American Adolescents' Religious Orientation, 1966-2014. PLOS ONE, 10, e0121454.

[20] Duque, E. (2013) Atitude dos Jovens Portugueses face á Religião. Plataforma Barómetro Social, 1-2.

[21] Stoppa, T.M. and Lefkowitz, E.S. (2010) Longitudinal Changes in Religiosity among 
Emerging Adult College Students. Journal of Research on Adolescence, 20, 23-38. https://doi.org/10.1111/j.1532-7795.2009.00630.x

[22] Braskamp, L.A. (2007) Fostering Religious and Spiritual Development of Students during College. Ankor Publishing, Chicago.

[23] Goergen, P. (2005) Educação e Valores no Mundo Contemporâneo. Educação \& Sociedade, 26, 983-1011.

[24] Kocet, M.M. and Stewart, D.L. (2011) The Role of Student Affairs in Promoting Religious and Secular Pluralism and Interfaith Cooperation. Journal of College \& Character, 12. https://doi.org/10.2202/1940-1639.1762 